\title{
Regulation and Liability of Credit Rating Agencies - A More Efficient European Law?
}

\author{
by \\ Thomas M.J. Möllers* and Charis NiedorF**
}

Credit rating agencies are said to be among those who caused the financial crisis. Both the United States and Europe have passed numerous laws intended to monitor them more closely. It stands undisputed, however, that these regulations do not suffice to solve the problems that evolved in the financial crisis. This article evaluates the European Commission's latest Credit Rating Agencies Regulation, which introduces, among others, two mandatory rating, sets a time limit on the contractual relationship between Rating Agency and the contracting entity and a civil liability regime. In order to effectively enforce the affected rights, two additional means must be introduced: Mandating a European rating could break the market's oligopolistic structure and help jump-start small European agencies. A civil liability regime can only serve as an incentive to introducing self-control if liability rules are truly deterring: To ensure that wrong ratings (such as Lehman Brothers') will actually lead to enforceable damage claims, the new Regulation needs to introduce a reversal of the burden of proof. This includes requiring the agency to immediately adjust a rating, avoiding an issuer's premature downscaling, and introducing a "rating out-look". In the article, several recent cases will be reviewed to assess the practicability of the new liability regime.

Table of Contents $\quad$ ECFR 2014, 333-363

I. Introduction . . . . . . . . . . . . . . . . . . . . . . . . . . . 334

1. Legal Framework before 2009 . . . . . . . . . . . . . . . . . . . . 334

2. European Regulation Efforts in the Context of the Financial Crisis . . 337

II. Overview of the Present Legislation $\ldots \ldots \ldots \ldots \ldots \ldots \ldots$

1. Avoiding Conflicts of Interest . . . . . . . . . . . . . . . 338

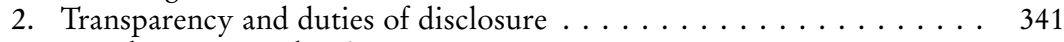

3. Mandatory second rating . . . . . . . . . . . . . . . 341

4. Other de lege ferenda proposals: Making financial market participants more independent of agencies' credit ratings . . . . . . . . . . . 342

III. Liability . . . . . . . . . . . . . . . . . . . . . . . . . . 346

1. The new liability regime of art. $35 \mathrm{a}$ of the rating regulation . . . . . . 346

2. Useful Extension by the European Court of Justice? . . . . . . . . . . . 349

* Professor Möllers teaches at the Chair for Civil Law, Economic Law, European Law, Conflicts of Law and Comparative Law at the University of Augsburg, Germany, and an Ad personam Jean Monnet Chair. He is Managing Director of the Center for European Legal Studies - CELOS.

** Ms. Niedorf works as a research assistant at the same chair. 
3. Case Studies: Insufficient quality control of the CRAs . . . . . . . . 350

4. Liability regimes around the world . . . . . . . . . . . . 352

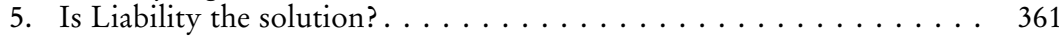

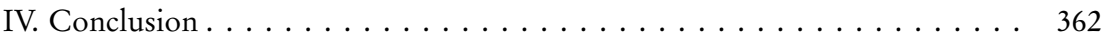

\section{Introduction}

Credit rating agencies are faced with harsh winds these days; the European lawmaker's efforts to regulate them advance and include the discussion whether a liability regime should be introduced. For the first time, companies question the market's oligopolistic structure and fierily criticize the ratings' pricing. ${ }^{1}$ Even among credit rating agencies, disagreements exist, as was seen when Fitch attacked its competitor Standard \& Poor's (S\&P) for what it believed to be too positive ratings. ${ }^{2}$ Headlines on rating mishaps ${ }^{3}$, controversial down-ratings of creditability ${ }^{4}$ and a number of law suits ${ }^{5}$ against credit rating agencies further fueled the discussion on regulating credit rating agencies. This article will first explain the former legal framework (II.) and what regulating efforts have been undertaken thus far (III.). It will then show which gaps exist in regulation and focus, in particular, on the intended introduction of a liability regime (IV).

\section{Legal Framework before 2009}

Over many years, European law did not know a comprehensive provision to monitor credit rating agencies. The system was based on the principle of self-

1 N.N., Deutsche Großkonzerne wehren sich gegen Preiserhöhungen von S\&P, Reuters, April 23, 2012, available at http://de.reuters.com/article/economicsNews/idDEBEE 83M09R20120423.

2 Shenn, Fitch again blasts S\&P grades on Credit Suisse mortage debt, December 3, 2012, available at www.bloomberg.com.

3 Gatinois/Lacombe/Michel, Le jour où la France a perdu son $<<$ AAA $\gg>$...par erreur, November 12, 2011, Le Monde.

4 N.N., US loses AAA credit rating after S\&P downgrade, BBC News, August 6, 2011, available at http://www.bbc.co.uk/news/world-us-canada-14428930.

5 N.N., Credit Rating Agencies settle 2 suits brought by investors, The New York Times, April 28, 2013, p. A4; Eaglesham/Neumann/Perez, U.S sues S\&P over Ratings, Wall Street Journal, February 5, 2013, available at www.wsj.com; Gullo, S\&P, Moody's, Fitch Lose Bid to Toss Calpers Lawsuit Claiming Negligence, Bloomberg, May 4, 2010, available at www.bloomberg.com; N.N., Klage gegen Ratingagentur zugelassen, Handelsblatt, November 28, 2011, available at http://www.handelsblatt.com/unternehmen/banken/ nach-lehman-pleite-klage-gegen-ratingagentur-zugelassen/5895788.html. 
regulation according to the IOSCO Code ${ }^{6}$ rules and on a recognition procedure as laid out in the Capital Requirements Directive. ${ }^{7}$ Even though the U.S. has had an authorization procedure for credit rating agencies since 1975, the European Union considered the existing standards as sufficient: ${ }^{8}$ It argued, inter alia, that additional authorization is not necessary as credit rating agencies depend on their reputation alone. An authorization procedure would isolate the market and make governments partly liable for published ratings. ${ }^{9}$ There are three elementary instruments which ensure the capital market's functioning: Avoiding conflicts of interest, information requirements, and surveillance. ${ }^{10}$ These instruments have not been developed sufficiently when dealing with credit rating agencies.

\section{a. Conflicts of Interest}

Since the 1970s, the "issuer pays"-model has been applied, requiring the issuer to pay for a rating's preparation. ${ }^{11}$ This model typically leads to a conflict of interests on part of the rating agency ("solicited rating"). ${ }^{12}$ When choosing an agency, companies thrive to be awarded the highest possible credit quality. Fitch's public criticism that S\&P allegedly rated too positively showed that

6 Code of Conduct Fundamentals for Credit Rating Agencies of the IOSCO (International Organization of Securities Commissions), available at http://www.eesc.euro $\mathrm{pa}$.eu/self-and-coregulation/documents/codes/private/065-private-act.pdf, last download 7.3. 2014.

7 Directive 2006/48/EC of the European Parliament and of the Council of 14 June 2006 relating to the taking up and pursuit of the business of credit institutions (recast), O.J. No. L 177, 1, and Directive 2006/49/EC of the European Parliament and of the Council of 14 June 2006 on the capital adequacy of investment firms and credit institutions (recast), O.J. No. L 177, 201.

8 See Communication from the Commission on Credit Rating Agencies, March 11, 2006, O.J. No. C 59, 2, 6: "Following the request by the European Parliament, the Commission has considered very carefully whether or not fresh legislative proposals are required to regulate the activities of credit rating agencies. Its conclusion is that at present no new legislative initiatives are needed."

9 On the argument, see e.g. Partnoy, 77 Wash.U.L.Q. (1999), 619, 627; Schwarcz, 1 U.Ill.L.Rev. (2002), 1; Fleischer, Gutachten F 64. DJT, 2002, F 134.

10 Möllers, 4 C.M.L.J. 477 et seq. (2009); Möllers, JZ 2009, 861 et seq.

11 Ellis/Fairchild/D'Souza, 7 VA.LBus.Rev(2013) 1, 2; Cinquegrana, The Reform of the Credit Rating Agencies: A Comparative Perspective, ECMI Policy No.12/February 2009, 2.2.

12 On the distinction between solicited and unsolicited rating, see Fulghieri/Srobl/Xia The Economics of Solicited and Unsolicited Credit Ratings, p. 1, available at http://papers. ssrn.com; for further information on conflict of interests see Darcy, Credit Rating Agencies and the Credit Crisis: How the "Issuer Pays" Conflict Contributed and What Regulators Might Do About It, 2009 Colum. Bus. L. Rev. 605. 
these fears are real. ${ }^{13}$ To further exacerbate the problem, prior to a rating, many companies are advised on how a financial product needs to be structured for it to reach the highest rating. So-called structured financial products such as collateralized debt obligations (CDO) proved especially disastrous in the course of the financial crisis. Though they are more dangerous and contain a higher risk than other products, they received best grades for reliability. ${ }^{14}$

\section{b. Missing Information}

The Efficient Capital Markets Hypothesis ${ }^{15}$ is the basis for informational duties. According to this hypothesis, all public information is "fed into" the market as soon as it becomes available to the investors. ${ }^{16}$ Research on behavioral finance shows that a "homo oeconomicus" who rationally processes information is a rare ideal: Stock exchanges overreact wave-like since they reflect their participants' emotion-driven behavior. ${ }^{17}$

The financial crisis showed that the information used by agencies and, consequently, the ratings themselves are not trustworthy: Subprime products received good grades, clearly under-rating their large risks. In addition, credit rating agencies failed to immediately adjust ratings to worsening market conditions. ${ }^{18}$

13 Though asked to evaluate the transaction, Fitch was denied the rating order "due to the agency's more conservative credit stance”, see Shenn, Fitch blasts S\&P grades on Credit Suisse mortage debt, Mar. 30, 2012, www.bloomberg.com.

14 The Financial Crisis Inquiry Report, Final Report of the National Commission on the Causes of the Financial and Economic Crisis in the United States, 2011, p. 127, available at http://www.gpo.gov/fdsys/pkg/GPO-FCIC/pdf/GPO-FCIC.pdf, last download 7.3.2014.

15 On the information deficit at the capital market and the Efficient Capital Markets Hypothesis (ECMH), see Fama, 25 J.Fin. (1970), 83; Fama, 46 J.Fin. (1991), 1575, 1576; Fischel, 74 Cornell. L. Rev. (1989), 907; Brealey/Myers, Principles of Corporate Finance, 7th ed., Boston 2003, pp.347 et seqq.; Elton/Gruber/Brown/Goetzmann, Modern Portfolio Theory and Investment, 6th ed. 2003, pp. 402 et seqq.

16 Fischel, 74 Cornell. L. Rev. (1989), 907.

17 Such as a lemming-like behavior, blindly complying with a finance guru's recommendations. On behavioral finance in general, see e.g. Thaler, Advances in Behavioral Finances Vol. I, Princeton 1993; Thaler, Advances in Behavioral Finances Vol. II, 2005; Goldberg/von Nitzsch, Behavioral Finance, $4^{\text {th }}$ ed. 2004; Fleischer, Behavioral Law and Economics im Gesellschafts- und Kapitalmarktrecht - ein Werkstattbericht, in: Fuchs/ Schwintowski/Zimmer (eds.), Wirtschafts- und Privatrecht im Spannungsfeld von Privatautonomie, Wettbewerb und Regulierung. Festschrift für Ulrich Immenga zum 70. Geburtstag, Munich 2004, pp. 575 et seqq.

18 Proposal for a Regulation of the European Parliament and the Council on Credit Rating Agencies, November 12, 2008, COM (2008) 704 final, 2; in depth Möllers, JZ 2009, 861 et seqq. 


\section{c. The Rating Market's Oligopolitistic Structure}

The world-wide market for credit ratings is still dominated by the three agencies S\&P, Moody's and Fitch. ${ }^{19}$ One reason for this market structure is the fact that companies choose credit rating agencies according to their reputation. A rating's reliability is measured by a long and well-documented history, the socalled track record. It shows whether an agency has delivered sufficiently good estimates in its ratings over a longer period of time. ${ }^{20}$ The rating market's oligopolistic structure creates dependencies and, at the same time, market access barriers ${ }^{21}$ for small and medium-sized credit rating agencies trying to establish themselves.

\section{European Regulation Efforts in the Context of the Financial Crisis}

a. Credit Rating Regulations No. 1060/200922 and No. 426/201323

When the subprime bubble burst, the European financial market policy had to be reconsidered. The credit rating agencies' failure is best corrected "by measures relating to conflicts of interest, the quality of the credit ratings, the transparency and [...] surveillance of the activities of the credit rating agencies"24. By introducing the Credit Rating Regulation 1060/2009 in November 2009, the European Union rejected the principle of self-regulation. ${ }^{25}$ The core of the Credit Rating Regulation is the requirement of registration in Art.14 Credit Rating Regulation and the registration procedure.

19 Together, SEP and Moody's have a market share of $80 \%$, the British credit rating agency Fitch is attributed further 15\%; see Hill, Regulating the Rating Agencies, 82 Wash.U.L.Q. 43, 59 et seq. (2004); Blaurock, ZGR 2007, 603, 606.

20 Zentraler Kreditausschuss, Stellungnahme zur Tätigkeit von Rating-Agenturen und ihrer möglichen Regulierung, August 14, 2003, p.5, available at http://www.zka-online.de/ uploads/media/030815_ZKAStn_Rating-Agenturen.pdf, last download March10, 2014. Only market niches remain for new providers; Strunz-Happe, WM 2004, 115, 120.

21 See Lerch, BKR 2010, 402, 403; Thörle, BLJ 2011, 14.

22 Regulation (EC) No. 1060/2009 ofthe European Parliament and of the Council of 16 September 2009, O.J. No. L 302, 1 (Credit Rating Regulation); Möllers, JZ 2009, 861, 870; Möllers, NZG 2010, 285, 288.

23 Commission Regulation (EU) No. 426/2013 of 8 May 2013 adapting Regulations (EC) No.1120/2009, (EC) No.1121/2009 and (EC) No.1122/2009 as regards implementing rules for direct payment in Croatia.

24 Recital 10 Credit Rating Regulation (Fn. 22).

25 Deipenbrock, RIW 2010, 612, 613. 
Regulation 1060/2009 was amended in 2013 by a Regulation and a Directive. The amending regulation 462/2013 addresses issues which have been not solved sufficiently by the first regulation or were left unregulated. The most significant innovation of this Regulation is the introduction of a civil liability regime.

\section{b. ESMA Regulations}

A clear mandate and a new structure to improve the effectiveness of surveillance had already been demanded in the Larosière Report ${ }^{26}$ in 2009. Since national authorities were still charged with materially examining the requirements for admittance as well as with regulatory tasks, the CESR was only engaged in case of conflict among the competent authorities. ${ }^{27}$ Thus, organizational need for coordination was significant. ${ }^{28}$ In the course of the ESMA Regulation $^{29}$, the ESMA (European Securities and Markets Authority) succeeded the CESR beginning January 1, 2011. The Amending Regulation ${ }^{30}$ transferred the exclusive competence to register and monitor credit rating agencies to ESMA. ${ }^{31}$ Thus the scope of competence of ESMA is finally defined as having the general competence in the field of rating agencies thus introducing a centralized European competence. ${ }^{32}$

\section{Overview of the Present Legislation}

\section{Avoiding Conflicts of Interest}

Art. 6 and 7 Credit Rating Regulation contain rules on how to deal with conflicts of interest and give general objectives such as avoiding that the credit

26 Larosière Group, Report on Financial Supervision in the EU of February 25, 2009, pp. 46 et seqq., http://ec.europa.eu/internal_market/finances/docs/de_larosiere_report_de.pdf.

27 Art. 24 Para. 3 Subpara. 2 Credit Rating Agency (Fn. 22).

28 See in detail Möllers, JZ 2009, 861, 870; Möllers, NZG 2010, 285, 288.

29 Regulation (EU) No. 1095/2010 of the European Parliament and the Council of 24 November 2010 establishing a European Supervisory Authority (European Securities and Markets Authority) amending Decision No. 716/2009/EC and repealing Commission Decision 2009/77/EC, O.J. No. L 331, 84 (ESMA Regulation).

30 Regulation(EU) No. 513/2011 of the European Parliament and of the Council of 11 May 2011 amending Regulation (EC) No. 1060/2009 on Credit Rating Agencies (Amending Regulation), O.J. No. L 145, 30.

31 Art. 148 c Amending Regulation (Fn. 30).

32 Regulation 513/2011/EU Recital 5. 
rating agency's business relations influence the rating. Annex I to the Credit Rating Regulation specifies these provisions in an organizational (Section A), operational (Section B) and personal (Section C) way. These rules have been amended by the new regulation adding an art. 6 a, which deals with conflicts of interest concerning investments in credit rating agencies. Its aim is to avoid conflicts of interest arising from members or shareholders of credit rating agencies investing in another agency.

\section{a. Advisory Services}

Previous advisory services by credit rating agencies create a large potential for conflicts of interest if the agency shapes the issuer's financial products with the highest possible credit quality rating in mind. The Credit Rating Regulation addresses this problem and prohibits such advisory services for the company to be rated..$^{33}$ Side services such as "market forecasts, estimates of economic trends, pricing analysis and other general data analysis" are explicitly admitted but must be disclosed in the credit rating agency's final report. ${ }^{34}$

Conflicts of interest also arise from long-lasting contractual relationships between credit rating agencies and rated entities, leading to too much familiarity and loss of objectiveness. ${ }^{35}$ Art. $6 \mathrm{~b}$ defines a maximum duration for these contracts ranging from two to four years depending on the product rated.

\section{b. "Issuer pays" Model}

The Regulation, however, does not address the "issuer pays"-model as the main source of conflict of interests. ${ }^{36}$ In this respect, the new provision fails to prevent these conflicts but solely reduces them. It would therefore be beneficial if a new category of unsolicited ratings evolved with these ratings being available to and for sale for other market participants. Thus far, a market for unsolicited ratings exists mostly for follow-up ratings. Competition ap-

33 Annex I Section B 4 No. 2, Annex I Section E II 2 a, Annex I Section E I 2 Credit Rating Regulation (Fn. 22).

34 Annex I Section B $\$ 2$ and 3 Credit Rating Regulation (Fn. 22).

35 Regulation Commission Regulation (EU) No. 426/2013 of 8 May 2013 adapting Regulations (EC) No.1120/2009, (EC) No.1121/2009 and (EC) No.1122/2009 as regards implementing rules for direct payment in Croatia, Recital 12.

36 Doubtful to the fact that the issuer-pays model generates conflicts of interest to a great extent: Partnoy, Law and Economic Research Paper No. 14, USD 08/27/01. 
pears to increase, though. The Egan-Jones Rating Company ${ }^{37}$, for instance, no longer offers solicited ratings but advertises that it is not subject to conflicts of interest. Alternatively, surveillance authorities could commission credit rating agencies to prepare a credit rating. Such commissioning is, for example, known in capital markets law when an auditor scrutinizes a securities company. Here, $\mathrm{BaFin}$ charges the auditor with examining whether a securities service company complies with its informatory and advisory duties. ${ }^{38}$ In the U.S., too, involving an intermediary was discussed. ${ }^{39}$ The SEC requested a feasibility study, the results of which were published in December 2012.40

In late 2011, ESMA presented a draft for regulatory technical standards ${ }^{41}$, intended to further improve the registration procedure's transparency and ongoing rating activities. Due to the new Regulation in 2013, the final version was delayed. ${ }^{42}$ ESMA discusses in detail whether the "issuer pays" model should be eliminated. ${ }^{43}$ The EU Commission's proposal for a new regulation, however, adheres to this model despite admitting that conflicts of interests exist. $^{44}$

37 Selfstatement on the website: "Egan-Jones Ratings is an independent ratings firm and not paid by corporations issuing bonds.” (http://www.egan-jones.com); Grant, Egan-Jones approved by new SEC-Register, Financial Times 15.1.2008, available at http://www.ft. $\mathrm{com} / \mathrm{cms} / \mathrm{s} / 0 / 0 \mathrm{c} 2342 \mathrm{b0}-\mathrm{c} 2 \mathrm{f} 1-11 \mathrm{dc}-\mathrm{b} 617-0000779 \mathrm{fd} 2 \mathrm{ac} . \mathrm{html}$, last download 7.3. 2014. Their business allegedly grew by $30 \%$ from 2007 to 2009 , but had to face a severe set-back when being banned from rating sovereign ABS for 18 month in January 2013, http:// www.bloomberg.com/news/2013-01-22/egan-jones-faces-18-month-ban-on-sovereign-asset-backed-ratings.html, last download 7.3.2014.

38 Möllers, ZJS 2009, 227, 231.

39 Bächstädt, KRP 4/2010, p. 24, available at http://www.ratingrisk.de/Baechstaedt_Fin_ Ratingagenturen.PDF, last download 7.3. 2014; Proposal by Senator Franken, available at http://www.dsnews.com/articles/sen-franken-and-others-address-rating-agency-re form-2011-09-01, last download 7.3.2014.

40 Securization Update by Kramer Levin Naftalis \& Frankel LLP, Jan. 2012, p. 8, available at http://www.kramerlevin.com/files/Publication/706e8e86-d4a2-4b69-8665-0b0bbbb 3c9f5/Presentation/PublicationAttachment/cf152c29-0b87-4dd6-840c-OfofaOf94073/

Securitization\%20Update\%20January\%202012.pdf, last download 7.3.2014.

41 ESMA, Final Report, Regulatory Technical Standards on the presentation of the information that credit rating agencies shall disclose in accordance with Article 11(2) and point 1 of Part II of Section E of Annex I to Regulation (EC) No.1060/2009, ESMA/ 2011/461, 22 December 2011, available at http://www.esma.europa.eu/system/files/ 2011_461.pdf, last download 7.3.2014.

42 Discussion Paper 20113/891, http://www.esma.europa.eu/news/ESMA-launches-con sultation-implementation-new-CRA-Regulation.

43 Bremer, NZG 2011, 1181.

44 The "issuer pays"-model Regulation (EU) No.462/2013 of the European Parliament and of the Council of 21 May 2013 amending Regulation (EC) No. 1060/2009 on credit rating agencies, Recital 10. 


\section{Transparency and duties of disclosure}

In addition to the rules intended to prevent conflicts of interest, credit rating agencies are faced with comprehensive duties of information and disclosure according to the Credit Rating Regulation. ${ }^{45}$ Artt. 8 and 10 Credit Rating Regulation, as well as art. 11, read in conjunction with Annex I Section E, specify the duties of disclosure with regard to methods, models and general assumptions upon which the credit ratings are based. Additionally, agencies are required to report their rating category's historic default rate every six months. ${ }^{46}$ Furthermore, credit rating agencies are required to publish a yearly transparency report which includes, inter alia, internal control mechanisms to ensure quality, method and model evaluations and the analysts' rotation policies. $^{47}$

\section{Mandatory second rating}

The newly introduced art. $8 \mathrm{c}$ requires two ratings for structured finance instruments. The aim is to ensure the rating's quality and minimize dependence. When engaging two credit rating agencies, the issuers shall consider to engage one agency that has less than $10 \%$ of the total market share, art. $8 \mathrm{~d}$ Para 1 . The regulation does not contain an obligation for a rating by a "small" credit rating company, because the issuer is free to decide against a rating by a small company. A negative decision only has to be documented, art. $8 \mathrm{~d}$ Para 1.

To this day, ESMA registered 37 credit rating agencies. ${ }^{48}$ On paper, therefore, interested parties can choose from many credit rating agencies. Despite these numbers, though, $95 \%$ of the rating market is dominated by S\&P, Moody's and Fitch. The new regulations are a first step to break the oligopoly but only time will show if issuers indeed appoint a smaller credit rating agency for a second rating. Smaller agencies could benefit from this regulation especially if the costs for ratings were lower. An obligatory second rating is an immense cost factor that issuers will try to keep as small as possible. Investors' perception of the second rating also needs to be factored in, as it is unclear whether they will be influenced by it or not.

45 In depth, Haar, ZBB 2010, 185, 188 et seqq.

46 Regulation No. 1060/2009 Annex I Sec. E II No. 1 (fn. 22).

47 Regulation No. 1060/2009 Art. 12 in conjunction with Annex I Section E Part III No. 2 and 3 (fn. 22).

48 List of registered and certified CRAs, February 6, 2012, available at http://www.esma. europa.eu. 
4. Other de lege ferenda proposals: Making financial market participants more independent of agencies' credit ratings

\section{a. Obligation to prove a European rating}

The current regulation still is far from satisfactory as small credit rating agencies only have to be taken into consideration where a second rating is mandatory. ${ }^{49}$ It remains to be seen whether this leads to a significant increase in ratings by these agencies. This regulation also fails to put a stronger emphasizes on a European perspective. Requiring a second mandatory rating to be European could strengthen European agencies and lead to more independence from the three big U.S. rating companies.

Considering the rating agencies currently admitted by ESMA, a European credit rating agency would need to be defined in detail. SEP is currently represented in the EU by three of its daughters, Moody's by six and Fitch by seven of its own. Thus, more than half of all credit rating agencies with an ESMA authorization are European subsidiaries of the "great three". ${ }^{50} \mathrm{De}$ manding an additional rating by an ESMA-authorized agency is therefore not satisfactory if not combined with other measures. In India, for instance, the rating market is dominated by three agencies which are mostly unknown here, namely, CRISIL, CARE and ICRA. ${ }^{51} \mathrm{~A}$ look at the shareholders shows, however, that Moody's holds $29 \%$ of ICRA. S\&P even owns the majority of CRISIL shares, $52 \% .{ }^{52}$ These numbers are significant proof for the American agencies' influence on the Indian rating market.

The proposal for one mandatory genuinely European rating does not constitute a breach of the General Agreement on Trades and Services (GATS) ${ }^{53}$. Credit rating as financial service is explicitly included in the GATS' scope of application, cf. $\$ 1$ (a) (xvi) of the annex. ${ }^{54}$ According to art. XVI $\$ 1$ GATS, GATS member states are required to allow access to their service markets to foreign companies in that the other member states' service providers must receive a treatment that is no less favorable than that agreed upon. ${ }^{55}$ For

49 See above II 3.

50 See List of registered and certified CRAs, January 6, 2012.

51 N.N., Letters from India, The Economist, March 17, 2012, p. 68.

52 N.N., Letters from India, The Economist, March 17, 2012, p. 68; CARE, on the other hand, is mainly held by Indian banks: IDBI Bank Ltd. (26\%), Canara Bank (23\%) and State Bank of India (9\%), http://www.careratings.com/AboutCARERatings/Sharehol ders.aspx.

53 BGBl. II, 1994, 1643 et seqq.

54 BGBl. II, 1994, 1660 et seqq.

55 See in detail Vabldiek, BKR 2003, 971 et seqq. 
Germany, that is the list of obligations of EU member states. ${ }^{56}$ By creating a second, mandatorily European rating, market access for other providers would not change. Non-European agencies could still access the European market since a "free" rating by established credit rating agencies remains possible. The credit rating market would simply be enlarged for European agencies. Furthermore, the GATS does not prohibit all measures which may have a deterring effect on foreign providers: "Notwithstanding any other provisions of the Agreement, a Member shall not be prevented from taking measures for prudential reasons, including for the protection of investors [...] or to ensure the integrity and stability of the financial system." ${ }^{57}$

Admittedly, even such laws cannot prevent the Great Three's increasing their presence on the European market, e.g. by buying out smaller agencies. However, it is not the goal of the regulation to exclude S\&P, Moody's and Fitch from the European Market. Instead, the rating market should be opened to European agencies and competition should be promoted in order to give a fair chance to these agencies. Requiring proof of a European rating could open doors in this context. Another positive effect of this proposal is that the creation of a "one and only" European credit rating agency is no longer necessary: the credit rating's independence would be ensured by competition among the European agencies, at the same time creating a counterweight for ratings which allegedly favor the U.S. ${ }^{58}$.

\section{b. Reducing links to the law}

\section{aa. CRD-IV Directive - Basel III}

Credit rating agencies became more important for European law of bank regulation when the Basel II Capital Requirements Directives ${ }^{59}$ were implemented..$^{60}$ The Basel accord intended to ensure that the capital requirements

56 Bekanntmachung des Fünften Protokolls zum Allgemeinen Übereinkommen über den Handel mit Dienstleistungen (=Official statement of the fifth protocol on the general convention on trade with services), BGBl. II, 1999, 312 et seqq.; BGBl. II, 1994, 1521 et seqq.

57 So-called "prudential carve-out", no. 2 a) of the attachment on financial services, BGBl. II, 1994, 1660.

58 See the thorough study by Fuchs/Gering, The Home Bias in Sovereign Ratings, Discussion Paper Series/University of Heidelberg, Department of Economics, No. 552, available at http://papers.ssrn.com/sol3/papers.cfm?abstract_id=2370374, last download 7.3.2014.

59 Directive 2006/48/EC of 14 June 2006, O.J. No. L 177, 1 and Directive 2006/49/EC of 14 June 2006, O.J. No. L 177, 201.

60 Haar, ZBB 2010, 185, 193; see, e.g. Art. 80 1. Directive 2006/48/EC: "Credit Quality 
take greater account of risks. The evaluation of risks is based on internal or external ratings which help to estimate the default probability for credit amortization. ${ }^{61}$ Thus, a credit institution's minimum capitalization depends on its debtors' solvency. In Germany, such credit ratings may only be performed by authorized credit rating agencies. ${ }^{62}$

Such legal references made supervision authorities dependent on ratings performed by non-governmental institutions, leading to asymmetric market mechanisms. ${ }^{63}$ This problem has since been recognized and the lawmaker reacted to reduce the legal recourse to a credit rating agency's assessment. The Basel III Accord provides that both ratings and other quality or quantity criteria determine if means can be charged as assets. Among those suitable criteria are, inter alia, size, bid-ask spread and turnover. As these criteria become more robust, they should become more important and external ratings should lose some of their importance. ${ }^{64}$ Offering further parameters to estimate solvency can help prevent excessive trust in external ratings alone.

The EU implemented these changes in 2013 in a Directive that substitutes the former Capital Requirements Directives (2006/48/EC and 2006/49/EC). The member states have to implement the new Directive by $2016 .{ }^{65}$ The package consists of a regulation on the activity of credit institutions and investment firms and a directive governing the access to deposit-taking activities and is intended to strengthen the European banking sector. ${ }^{66}$ Inter alia, banks will no longer be able to base their investment decisions on external ratings, but must also make their own, internal solvency evaluation. ${ }^{67}$ Furthermore, if a significant number of positions in a portfolio remain open, an internal rating for this portfolio must be created. These measures aim at reducing the importance of

may be determined by reference to the credit assessments of External Credit Assessment Institutions [...]."

61 See Becker, DB 2010, 941, 943.

62 Sec. 41, 52 et seq. Solvabilitätsverordnung - SolvV (= Regulation governing the capital adequacy of institutions, groups of institutions and financial holding groups) (14.12. 2006), last amended by art. 6 Regulation of 20 September 2013 (BGB1. I, 2013, 3672).

63 Lerch, BKR 2010, 402; Siekmann, Verw 43, 95, 105; Deipenbrock, WM 2005, 266 et seqq.; Deipenbrock, WM 2006, 2237 et seq.

64 Basel Committee on Banking Supervision, Basel III: International framework for liquidity risk measurement, standards and monitoring, December 2010, p. 11, available at http://www.bis.org/publ/bcbs188.pdf, last download 7.3.2014.

65 Directive 2013/36/EU of the European Parliament and of the Council of 26 June 2013 on access to the activity of credit institutions and the prudential supervision of credit institutions and investment firms, amending Directive 2002/87/EC and repealing Directives 2006/48/EC and 2006/49/EC.

66 Art. 9 Directive 2013/36/EU.

67 Art. $76 \$ 2$, art. $77 \$ 2$ Directive 2013/36/EU. 
external ratings for credit institutions. ${ }^{68}$ On the one hand, institutions are to be attracted to creating their own evaluation systems. On the other hand, standardized approaches remain that are based on external ratings. Mainly, financial institutions are to be led to a point at which they do not blindly trust external ratings but make their own judgments with the help of internal evaluations. ${ }^{69}$ This reduces dependency on external ratings without eliminating the Basel II Accord's principle ${ }^{70}$ since the requirement of own funds should still be based on external ratings to a "necessary extend" ${ }^{71}$

\section{bb. Solvency II}

When solvency rules ${ }^{72}$ were introduced, ratings became more important to the European insurance market as well. Capital requirements for insurance companies are to be developed into a risk-oriented system of financial supervision and the insurers' internal risk management is to be improved..$^{73}$ Here, too, determining the probability of default lies at the center. Solvency II leaves it up to the businesses to choose a method for measuring risk. Internal and external evaluation models can be used if they are officially recognized. In 2010, 289 of 2520 European insurance companies confirmed working on implementing an internal model; 262 undertakings were already using such model..$^{74}$ Currently, about one third of life and health insurances and a quarter of indemnity and accident insurers in Germany use BaFin-authorized internal models. ${ }^{75}$

The credit rating agencies' regulatory dependency in the insurance field is not induced by the legal framework. It is obvious, however, that only large international insurance companies have such models. ${ }^{76}$ Mostly small and midsized

68 Recital 70, 71, 72 Directive 2013/36/EU.

69 Recital 72 Directive 2013/36/EU.

70 see e.g. Recital 70 Directive 2013/36/EU.

71 Recital 70 Directive 2013/36/EU.

72 Directive 2009/138/EC of the European Parliament and of the Council of 25 November 2009 on the Taking-Up and Pursuit of the Business of Insurance and Reinsurance (Solvency II), O.J. No. L 335, 1.

73 see e.g. Recital 102 and Chapter VI Section 4 Directive 2009/138/EC.

74 EIOPA Report on the fifth Quantitative Impact Study (QIS5) for Solvency II, EIOPATFQIS5-11/001, 14.3.2011, p.106, available at https:/eiopa.europa.eu/publications/ reports/index.html.

75 BaFin - Ergebnisse der fünften quantitativen Auswirkungsstudie zu Solvency II (QIS 5 results for Germany), p. 22, available at http://www.bafin.de/SharedDocs/Veroeffentli chungen/DE/Berichte/be_100716_qis5_va.html,.

76 Kaserer, Solvency II und Basel III, Die Reform der europäischen Versicherungs- und Bankenregulierung und deren Auswirkungen auf die Unternehmensfinanzierung, June 2011, p.16, available at http://www.fpmi.de/tl_files/fpmi/downloads/de/Gutachten_ im_Auftrag_der_fpmi.pdf. 
service providers will fall back on external ratings. ${ }^{77}$ Both Solvency II and Basel III promote using internal risk-analyzing models to reduce dependency on external ratings. It is to be feared, however, that credit institutions will have problems similar to those of insurance companies where internal ratings are concerned.

\section{Liability}

\section{The new liability regime of art. 35 a of the rating regulation}

The most important innovation of the new regulation is the introduction of a civil liability regime. Art. 35 a reads:

"1. Where a credit rating agency has committed, intentionally or with gross negligence, any of the infringements listed in Annex III having an impact on a credit rating, an investor or issuer may claim damages from that credit rating agency for damage caused to it due to that infringement.

"An investor may claim damages under this Article where it establishes that it has reasonably relied, in accordance with Article 5 a (1) or otherwise with due care, on a credit rating for a decision to invest into, hold onto or divest from a financial instrument covered by that credit rating.

"An issuer may claim damages under this Article where it establishes that it or its financial instruments are covered by that credit rating and the infringement was not caused by misleading and inaccurate information provided by the issuer to the credit rating agency, directly or through information publicly available. [...]”

It grants the investor a right of redress when relying on a rating issued in breach of Regulation 1060/2009. Also, issuers who suffered damages caused by a breach of the same regulation are compensated. The possibility of claiming damages is available for both groups regardless of any contractual relationships between the parties.

\section{a. Breach of Duty}

Liability requires a breach of one of the duties listed in Annex III of the regulation and that this breach has had an impact on the credit rating. An extensive list of duties was added to Annex III to Regulation No.1060/2009. Among others, an infringement constitutes liability if conflicts of interest exist because of personal involvement as defined by the Regulation or if rotation duties are not fulfilled. ${ }^{78}$ Furthermore, credit rating agencies are liable if they do not appro-

77 Arneth/Sauka, Kreditwesen 2008, 796, 799, available at http://www.meag.com/reddot/ downloads/de/Solvency_II.pdf.

78 Regulation 1060/2009/EU, Annex III no. I 19 to 21, 33, 26a-b, 38-40. 
priately ensure that ratings are based on a thorough analysis of all available information. Methods and ratings must continuously be monitored..$^{79}$ Another way to become liable is to breach the extensive duties of disclosure toward ESMA and the public. ${ }^{80}$

\section{b. Reliance}

Investors can only claim damages if their investment decision was based on the rating and if such reliance was legally admissible. Investors have to prove that they exercised due care when relying on the rating. This poses an immense restriction on liability. According to art. 5 a, all entities listed in art. 4 (1) have to make their own risk assessments and may not solely or automatically rely on other credit ratings. These entities include all institutional investors. Institutional investors are the group most likely to claim damages against credit rating agencies. Since art. 5 a requires them to make their own assessments, it is virtually impossible for them to claim that they still relied on the (outside) rating to an extend that justifies a damage claim: If both forecasts are identical, the investor does not rely solely on the credit agency's rating. If the investor's assessment differs from the agency's rating, no investor who trusts his own assessment will instead rely on that of the agency as such reliance would imply that he did not sufficiently fulfill his duties laid out in art. 4 (1). At the very least, an investor exercising due care cannot rely on a credit agency's rating if he has reason to believe that this rating is wrong. Such reason exists if other assessments (i.e. his own) differ from the agency's rating.

The requirement for reliance was not a part of the Commission's initial proposal. ${ }^{81}$ The consequences of this requirement deeply affect the liability regime. This provision in practice restricts liability claims to private investors, which was not initially intended by the legislature. A liability claim by those most likely to sue is thus practically prevented.

Private investors do not have an obligation for an own risk assessment thus may rely generally on ratings. This reliance is restricted by the requirement of reasonableness. Consequently a private investor would have to prove that he reasonably relied on the rating alone. This is very difficult in cases where there is media coverage that opposes or confirms the rating. In other words, it is virtually impossible to prove specific causation of the rating for the investment decision.

79 Regulation 1060/2009/EU, Annex III no. I 42, 46, 46 a.

80 Regulation 1060/2009/EU, Annex III no. II 3 a, 3 b, 4 a.

81 Com (2011) 747. 


\section{c. Burden of proof}

The regulation on the burden of proof is the drawback of the whole liability regime. In the initial proposal of the Commission ${ }^{82}$, the burden of proof was shifted, benefitting the investor. This shift was supported by the fact that the investor generally has no insight into the internal rating procedure and therefore faces adamant obstacles for national liability claims. ${ }^{83}$

This proposal was not adopted. ${ }^{84}$ The claimant now has to present all necessary information indicating that the credit rating agencies has committed the specific infringement. ${ }^{85}$ Moreover, the claimant has to present detailed and accurate information proving that the breach had an impact on the rating. Keeping in mind that by the chosen formulation the damage claim is in practice limited to private investors, it seems to be highly unlikely that they will be able to present any such information. Even for institutional investors, this threshold is hard to pass.

Although the court should take into account that the investor or issuer may not have access to all relevant information, ${ }^{86}$ the regulation leaves the general burden of proof with the claimant. The biggest problem in damage claims, as seen in the case of $\mathrm{Lehman}^{87}$, remains unsolved. Considering the chosen regulation on the burden of proof, the liability regime remains a theoretical claim. However, this provision was not adopted as it was found to be inappropriate. ${ }^{88}$ Shifting the burden of proof on the credit rating agencies changes the legal principle unilaterally towards the defendant.

82 COM (2011) 747 Recital 26.

83 Such as sec. 826 BGB and sec. 280 para. 1, 311 para. 3 sentence 2, 241 para. 2 BGB.

84 Arguing against a reversed burden of proof: Opinion of the Committee on Legal Affairs for the Committee on Economic and Monetary Affairs on the proposal for a regulation of the European Parliament and of the Council amending Regulation (EC) No.1060/ 2009 on credit rating agencies (COM (2011)0747 - C7-0420/2011 - 2011/0361 (COD)), 3.5.2012, p. 3 .

85 Regulation 462/2013/EU art. 35 a para. 2.

86 Regulation $462 / 2013 /$ EU art. 35 a para. 2.

87 He argued that "it is nearly impossible for the impaired investor to prove that the defendant rating agency violated its duties when creating the rating since the rating procedure lacks transparency and private investors in particular lack professional knowledge of the matter". Therefore, he demanded the burden of proof to be reversed, ordering the defendant to prove the rating's lege artis creation, Complaint, p. 5 et seq. (Fn. 120).

88 Opinion of the Committee on Legal Affairs for the Committee on Economic and Monetary Affairs on the proposal for a regulation of the European Parliament and of the Council amending Regulation 1060/2009/EU on credit rating agencies (COM (2011)0747 - C7-0420/2011 - 2011/0361 (COD)), 3.5.2012, p.3. 


\section{d. Loss and Causation}

The regulation does not define "damage". What constitutes it can thus be interpreted in accordance with the applicable national law. In general, two positions are possible: Claiming the difference in market rate (price causation $)^{89}$ or reversing the investment deal ${ }^{90}$.

In the first scenario, the damages claim is based on the idea that a financial product was either purchased too expensively when compared to a hypothetical correct price or sold for what was actually too low a price. ${ }^{91}$ Bringing forward evidence for a market rate loss is typically very difficult as it includes the presumption that a falling market rate expresses "how wrong" a credit rating was. ${ }^{92}$ Even though the impaired investor can involve an expert, the expert will face problems establishing a hypothetically correct market rate, putting the investor at a significant risk. For one, a market rate difference does not automatically equal the rating's degree of fault but factors many other criteria such as market expectations. Also, it would be difficult to prove the chronological connection of the rating and the moment of loss, as the market rate effect of any given information is, in time, displaced by other factors. ${ }^{93}$

Alternatively, the investor can claim that the credit rating was the reason for his investment decision. Loss is then defined as the difference between the financial product's actual worth after the rating and the situation the investor would be in if he had never decided to buy. The damage claim then includes the "negative interest", i.e. the "damage for having made a contract" 94 . As evidence, the investor must then bring forward facts which prove that he generally favors an investment strategy which is low in risk, arguing that a financial product with a positive rating thus fit his portfolio. ${ }^{95}$

\section{Useful Extension by the European Court of Justice?}

The above - mentioned criticism may partly be based on a genuinely German interpretation of the law. In practice, the law will be interpreted independently by the European Court of Justice $(\mathrm{ECJ})^{96}$, i.e. from a European perspective.

89 Vasella, Haftung von Ratingagenturen, 2011, p. 370.

90 See also Bachmann, JZ 2012, 578 et seqq.

91 Vasella, Haftung von Ratingagenturen, 2011, p. 370.

92 Vasella, Haftung von Ratingagenturen, 2011, p. 371 et seqq.

93 Vasella, Haftung von Ratingagenturen, 2011, p. 372.

94 Barth, Schadensberechnung bei Haftung wegen fehlerhafter Kapitalmarktinformation, 2006, p. 195.

95 Vasella, Haftung von Ratingagenturen, 2011, p. 375.

96 ECJ, dec. of 23. 4. 1986, case no. C-294/83, (1986) ECR 1357, margin no. 23 - Les Verts. 
The ECJ might interpret the conditions for liability according to the principle of the effet-utile. Interpreting for example European anti-trust laws, the ECJ invented a civil liability claim emphasizing its enforceability. Additionally, antitrust law allows estimated damage claims. ${ }^{97}$ If the ECJ transferred these interpretations to the liability of rating regimes, this would result in a liability relief with regards to causation and the amount of damages. Finally, it is established in antitrust law that the claimant may use the finding of the regulatory authority for his claim.

\section{Case Studies: Insufficient quality control of the CRAs}

\section{a. Australia-Rembrandt}

S\&P was sentenced to 20 million AU\$ monetary compensation by the Federal Court of Australia (Sydney) ${ }^{98}$ in November 2012.99 Twelve councils brought the case against the credit rating agency after having invested in $\mathrm{CPDOs}^{100}$ which were rated AAA. During the financial crisis they lost about $90 \%$ of the 16 Mio AU\$ they invested. The CPDO (so-called Rembrandt notes) were created by ABN AMRO and rated by S\&P. The Local Government Financial Services Pty Limited (LGFS) bought these Rembrandts notes and sold them to the councils.

The court ruled that assigning a AA rating to an instrument implies that the product is safe and that the rating is the result of a sound and thorough risk assessment. ${ }^{101}$ The verdict found that the credit rating agency and the bank

97 COM (2013) 404 final.

98 Bathurst Regional Council v Local Government Financial Services Pty Ltd (No. 5) [2012] FCA 1200, available at http://www.imf.com.au/pdf/Judgment\%20of\%20Jagot \%20J\%20dated\%205\%20November\%202012\%20re_\%20Local\%20Government\% 20Financial\%20Services\%20Pty\%20Ltd\%20\%28No\%205\%29.pdf.

99 Battersby, Standard \& Poor's hit with $\$ 20 \mathrm{~m}$ compensation for wonky ratings, The Sydney Morning Herald of 6.11.2012, http://www.smh.com.au/business/standardpoors-hit-with-20m-compensation-for-wonky-ratings-20121105-28u32.html, last download 7.3.2014.

100 CPDOs are credit derivates, which make money through notional credit default swap contracts (CDSs) referencing the Globoxx (i.e. CDX and iTraxx indices together; both are indices for credit default swap contracts (CDSs).). They operate over a term of 10 years and are highly leveraged (up to 15 times). For all the details on CPDOs, see Cont/ Jessen, Constant Proportion Debt Obligation (CPDO): Modeling and Risk Analysis, Financial Engineering Report No.2009-01, 2.4.2009, available at http://papers. ssrn.com/sol3/papers.cfm?abstract_id=1372414.

101 Bathurst Regional Council v Local Government Financial Services Pty Ltd (No. 5) [2012] FCA 1200, margin no. 2846 (fn. 98). 
had been negligent and deceptive. The credit rating agency awarded a rating they knew was not sound and thus mislead potential investors. ${ }^{102} S \mathcal{E} P$ did not seek out more information than were provided by the bank and based their risk assessment entirely on this information. When S\&P became aware of new developments such as decreased spreads, they did not initiate a new rating. ${ }^{103}$ The rating agency filed appeal; the hearing was scheduled to begin 3 March 2014. ${ }^{104}$

\section{b. Germany-Lebman}

In June 2010, an investor filed suit against S\&P with the Regional Court (Landgericht) Frankfurt/Main because of the Lehman rating. The damages claim is 30,000 euros. The plaintiff had bought Lehman certificates which were rated A+ by the credit rating agency. When the bank collapsed in September 2008, the certificates were rendered worthless for the investor. In court, he claimed that Lehman's creditability would not have been graded "good" but "precarious" or "in danger of default" if the necessary scrutiny had been applied. Such a negative rating would have been obligatory because there was no sufficient amount of capital available to cover the risks. Additionally, despite the press's intense reporting of Lehman Brothers' insolvency threat, S\&P held on to the "A+" grade until three days before the actual bankruptcy. Plaintiff claimed that the credit rating agency was liable for the injury which occurred because of its "breach of monitoring and adapting duties" according to the principles of the contract with protective effect to the benefit of third parties.

The plaintiff failed at first for lack of venue. In second instance, the Higher Regional Court $(O L G)$ Frankfurt complied with the plaintiff's argument. This decision was confirmed by the Federal Court of Justice $(B G H)$. After a second decision by the Higher Regional Court the case was remitted to the Regional Court Frankfurt/Main. This court has not yet decided the case.

102 "misleading and deceptive conduct", Summary of Bathurst Regional Council v Local Government Financial Services Pty Ltd (No. 5) [2012] FCA 1200, figure 53.

103 Bathurst Regional Council v Local Government Financial Services Pty Ltd (No. 5) [2012] FCA 1200, margin no. 2800 (fn. 98).

104 Schneider, S\&P, ABN Appeal Australian Ruling Ratings Misled Towns, March 3, 2014, http://www.bloomberg.com/news/2014-03-03/s-p-abn-appeal-australian-ruling-rat ings-misled-towns.html. 


\section{c. USA - Settlement against SEP}

In February 2013, the U.S. department of justice filed a claim against S\&P which can be considered historic. ${ }^{105}$ Subject of the dispute is the rating of bundles of subprime mortgages and collaterized debt obligations (CDOs). S\&P allegedly assigned ratings which they knew did not reflect the true credit risk of instruments. This behavior of credit rating agencies is "believed to have contributed to the worst economic crisis in recent history". ${ }^{106}$

Unfortunately, this unprecedented suit by government officials was not followed by what would have been a landmark decision as the parties reached a settlement. Without a judgment and thus lacking an extensive summary of the facts, it is impossible to evaluate this case under the various legal frameworks discussed below.

\section{Liability regimes around the world}

a. Liability under E.U. Law

aa. The new Art. 35 a

Credit rating agencies can be held liable if they do not have "sound administrative or accounting procedures [...and] effective procedures for risk assessment [...]"107. They are also obliged to "immediately assess [...] whether there are grounds for re-rating or withdrawing an existing credit rating or rating outlook"108. Furthermore, the methodologies used have to be rigorous, systematic, continuous and subject to validation"109. The rating has to be monitored and reviewed at least annually. ${ }^{110}$ To ensure this monitoring, the agency has to establish a system that monitors impacts on issued ratings by macroeconomic changes or conditions on the financial market. ${ }^{111}$ If mistakes in rating model or in their applications occur, the credit rating agencies have to re-rate the product. ${ }^{112} \mathrm{~A}$ credit rating agency may not issue (or if it has already

105 Neumann/Perez/Eaglesham, U.S., S\&P settle in for bitter combat, The Wall Street Journal, February 6, 2013, http://online.wsj.com/article/SB100014241278873244459 04578285802822704578.html.

106 Press Release, The Department of Justice, February 5, 2013, http://www.justice.gov/ opa/pr/2013/February/13-ag-156.html.

107 Directive 1060/2009/EC Annex III, I No. 12.

108 Directive 1060/2009/EC Annex III, I No. 21.

109 Directive 1060/2009/EC Annex III, I No. 42.

110 Directive 1060/2009/EC Annex III, I No. 46.

111 Directive 1060/2009/EC Annex III, I No. 47.

112 Directive 1060/2009/EC Annex III, I No. 49 a. 
issued, has to withdraw) a rating in case there is no reliable data or a credible rating cannot be provided due to the complex structure or the quality of the available information on a financial instrument. ${ }^{113}$

\section{bb. Lehman under the new E.U. Liability Regime}

In the Lehman case, the "A" rating was upheld by S\&P until three days before bankruptcy. This implied that Lehman had no financial problems or at least was not faced with bankruptcy. Considering the massive news release about the bankruptcy threat for Lehman ${ }^{114}$, such discrepancy between ex-post reality and credit rating cannot be assigned to any subjective discretion by the analysts in terms of detail adaption. Instead, publicly available information was not or not correctly evaluated, the rating was not updated and investors were not informed.

A comparable future case would result in liability according to art. $35 \mathrm{a}$ in conjunction with Annex III No. 21. According to the newly introduced provision, a credit rating agency is liable if it does not immediately assess "whether there are grounds for re-rating or withdrawing an existing credit rating or rating outlook" 115 . The broad media coverage as in the Lehman case is without any doubt an event that demands immediate re-rating. However, two problems remain: The plaintiff might have difficulties in proving that he reasonably relied on the rating for his decision to hold onto the certificates as the information of the impending insolvency was made publicly available in various news media ${ }^{116}$. When all other information opposes the rating, a reliance on this rating does not seem "reasonable" and not convincing. Furthermore, the burden of prove remains an insurmountable obstacle especially for private investors.

113 Directive 1060/2009/EC Annex III, I No. 50.

114 see e.g. Anderson, At Lehman, Allaying Fears About Being the Next to Fall, March 18, 2008, New York Times, http://www.nytimes.com/2008/03/18/business/18lehman. html?versio\&_r=0; Boyd, Lehman chief fells the heat, June 12, 2008, http://money. cnn.com/2008/06/12/news/companies/lehman_management.changes.fortune/index. htm?section=money_latest; Onaran, Lehman Drops After Fuld says Fed Eased Cash Concerns, March 17, 2008, http://www.bloomberg.com/apps/news?pid=newsarchive \&sid=aSEbPERHCk3Q\&refer=home.

115 Directive 1060/2009/EC Annex III, I No. 21.

116 Anderson, At Lehman, Allaying Fears About Being the Next to Fall, March 18, 2008, New York Times, http://www.nytimes.com/2008/03/18/business/18lehman.html? versio\&_r=0; Boyd, Lehman chief fells the heat, June 12, 2008, http://money. cnn.com/2008/06/12/news/companies/lehman_management.changes.fortune/index. htm?section=money_latest; Onaran, Lehman Drops After Fuld says Fed Eased Cash Concerns, March 17, 2008, http://www.bloomberg.com/apps/news?pid=newsarchive \&sid=aSEbPERHCk3Q\&refer=home. 


\section{b. Liability under German Law}

\section{aa. Intentional Damage Contrary to Public Policy}

In addition to liability under the new art. 35 a, liability under German law has to be considered, as further liability claims based on national law are not excluded by the Regulation, art. 35 a No.5. Under German law, a liability for intentional damage contrary to public policy (Sec. 826 BGB) could be considered even if the infringement was only committed negligently. Simple negligence only requires experts to give advice not founded on sound facts or without thorough identification of necessary information. ${ }^{17}$ The German Federal Court of Justice $(B G H)$ considers a behavior to be reckless if someone strives for his own benefit without respecting the interests of others. ${ }^{118}$

\section{bb. Lebman under German Law}

For a successful damages claim under Sec. 826 BGB in the Lehman case, plaintiffs must prove that $S \& P$ intentionally inflicted damages on them. The defendant must have acted negligently in not promptly changing the rating when new information was available thus intentionally causing the plaintiff's damages. There is no doubt that S\&P acted negligently, i.e. not founding the rating on sound facts when not considering the new information on the impending insolvency. However, it will be very difficult for the plaintiff to prove that S\&P's not changing the rating intended to inflict damages on investors. It will also be impossible to prove that the wrong rating was the cause, legally defined as a "condition sine qua non", for the plaintiff's decision to hold onto the certificates. Plaintiff has to prove a causal link between the rating and his decision. Considering the amount of publicly available information on the economic situation of Lehman Brothers, the production of necessary evidence remains doubtful.

The case would, however, appear in different light if S\&P, instead of not changing the rating at all, had uprated Lehman in spite of the negative media. Such a "new" credit rating would have signaled that S\&P possessed insider knowledge with regards to the economic situation of Lehman Brother. In this case, liability under Sec. 826 BGB would exist because a positive credit rating against better judgment constitutes an intentional damage contrary to public policy. ${ }^{119}$ The

117 BGH 24.9.1991 NJW 1991, 3282, 3283 - Bodengutachten with further references; consenting Staudinger/Oechsler ${ }^{13}$, BGB, $\$ 826$ Rdn. 213.

118 BGH 24.9.1991 NJW 1991, 3282, 3283 - Bodengutachten with further references; consenting Staudinger/Oechsler ${ }^{13}, \mathrm{BGB}, \mathbb{8} 826 \mathrm{Rdn} .213$.

119 Möllers/Leisch, in: Kölner Kommentar zum WpHG, 2nd ed. 2014, \$§37 b, c para. 444 et seqq. 
credit rating agency acts with intent to cause damage because they know that investors trust in their rating and that giving a positive signal opposing other news and information especially suggests that they have a superior knowledge. The agencies know that under such circumstances they inflict damage on the investors and hence act intentionally.

\section{cc. Rembrandt under German Law}

The behavior of S\&P in Rembrandt constitutes an intentional damage contrary to public policy (Sec. $826 \mathrm{BGB}$ ). Credit rating agencies know that investors trust in their risk assessment (this trust precisely is their reputational capital). When they publish a rating that is not thoroughly researched and is not adapted to new developments, it is obvious for them that they inflict damages on the investors. The Rembrandt notes are a financial product that is so highly structured, packaged, repackaged and leveled that investors will not have the insight and capacity to make an own risk assessment. A market for such a product is initially created by a positive rating; with a realistic rating, Rembrandt notes would have most probably never been bought; at least not by councils. Thus giving a too positive rating without an own thorough risk analysis, the credit rating agency knowingly and intentionally inflict damages.

\section{c. Liability under English law}

\section{aa. Tort of deceit}

The tort of deceit is one category of misrepresentation. ${ }^{120}$ Deceit requires an actual "intention to cheat" 121 , i.e. the defendant has to know that his statement is false or is made reckless to whether the stated facts are correct or not. ${ }^{122}$ The plaintiff has the burden of proof for the deceptive behavior. ${ }^{123}$

Unlike wrong statements, a wrong prognosis does not constitute a breach of law. ${ }^{124} \mathrm{~A}$ statement that is only a subjective opinion is no representation of fact as required by torts law. ${ }^{125}$

120 Proser/Wade/Schwartz, Torts, 9th ed. 1994, p. 1013.

121 Nocton v. Ashburton, [1914] A.C. 932, 953.

122 Derry v. Peek (1889), HL 14 App. Cas. 337; Shears/Stephenson, James' Introduction to English Law, 13 ${ }^{\text {th }}$ ed. 1996, p. 258; Thomas, in: Thorne/Prentice, Butterworths Company Law Guide, $4^{\text {th }}$ ed. 2002 , p. 334.

123 Wallingford v. Mutual Society (1880), HL 5 App. Cas. 685.

124 Shears/Stephenson, James' Introduction to English Law, 13 th ed. 1996, p. 258.

125 Shears/Stephenson, James' Introduction to English Law, 13 th ed. 1996, p. 258. 
The "intention to cheat" was first specified by a decision by the House of Lords in 1889 called Derry v. Peek ${ }^{126}$. The chairman of a railway company issued a prospectus stating that the Plymouth Tramway Company had been authorized to work (mechanical) tramways. The Board of Trade, however, refused to consent to the use of tramways without horse powers. The chairmen sincerely believed either that the consent had been obtained or that obtaining it was only a matter of formality. Consent, however, was denied. Before the final denial, the plaintiff applied for and allotted shares in the company, believing the statements of the prospectus. The company was wound up due to the missing consent causing the plaintiff to lose his invested money. The House of Lords dismissed the action because the belief of the chairmen in obtaining the consent was not unreasonable, careless or reckless.

In the meantime, the duties of the management board regarding prospectuses were substantially aggravated. The principle established in Derry v. Peek remains that a false statement is not fraudulent when it is believed to be true. ${ }^{127}$

When applying these requirements on ratings, the credit rating agency could only be held liable if they published ratings which they knew were wrong or based on wrong facts. As long as the publishing company would believe in the truthfulness of their ratings and this belief was not unreasonable, careless or reckless, a claim under the tort of deceit is impossible. The main obstacle is the burden of proof. As long as the plaintiff has to prove that the belief was careless or reckless, a liability claim seems to be not very promising.

\section{aa. Tort of negligence (negligent misstatement)}

Furthermore, damages in English law might be awarded for a negligently wrong rating. The leading case concerning torts of negligence was Hedley Byrne v. Heller $\mathcal{E}$ Partners Ltd ${ }^{128}$. The House of Lords clearly stated the conditions for tortious liability regarding negligently wrong statements. Prior to this decision, there was the consensus view that negligent wrong statements, as opposed to fraudulent deceptions, did not justify damage claims. Damages claims were only granted if a special (in most cases contractual) relationship existed. ${ }^{129}$ This criterion was softened; a particular proximity between the parties was declared sufficient for liability.

The tort of negligence has three factual requirements: First of all, the publisher of the statement has to be able to foresee that the recipient will trust in his

126 Derry v. Peek (1889), HL 14 App. Cas. 337.

127 Shears/Stephenson, James' Introduction to English Law, 13 th ed. 1996, p. 259.

$128 \quad 2$ All E.R. 771.

129 Shears/Stephenson, James' Introduction to English Law, 13 th ed. 1996, p. 319; Caparo Industries Plc v Dickman [1990] 2A.C. 605, 609 margin no.F, G. 
statement. There has to be a particular proximity between the two parties though a contractual relationship is not required. ${ }^{130}$ Finally, it has to be reasonable from a legal point of view to impose a special duty of care on the publisher.

\section{cc. Rembrandt under English Law}

Liability of credit rating agencies as tort of negligence seems reasonable when applying the above mentioned criteria on the Australian case. Every credit rating agency can foresee (and knows) that investors trust in their ratings. The very idea of credit ratings is based on trust. ${ }^{131}$ It remains problematic, however, to construct a particular proximity between credit rating agencies and investors, as there is only a contract between agency and rated entity. Proximity does not only exist where there is a contract between parties but also when the plaintiff is part of the intended audience, which is the (potential) investors. However, this group could be too large and undefined, leading to unlimited and unpredictable liability. Whether or not the relationship between credit rating agencies and (all potential) investors meets the requirements has yet to be decided and appears very doubtful.

The same doubts rise when applying English Law to the Lehman case.

\section{d. Liability under U.S. law}

\section{aa. Legal Framework}

Basis of liability under U.S. law is Sec. 10(b) SEA read in conjunction with Rule 10b-5 concerning material misstatements and omissions. ${ }^{132}$ Rule 10b-5 does not explicitly require intentional infringement. This lack resulted in 20 years of discussion on whether intentional or negligent behavior was covered by the regulation. ${ }^{133}$ The question was decided by the Supreme Court in 1976 in the case of Ernst \& Ernst v. Hochfelder ${ }^{134}$. For a claim under Rule 10b-5, plaintiff has to prove that the defendant acted with scienter. Basis of the decision is the proximity of Rule $10 \mathrm{~b}-5$ to a common law fraud which requires manipulation, deception and deliberate action. ${ }^{135}$

130 See Caparo Industries Plc v Dickman [1990] 2A.C. 605, 610 margin no. B.

131 Partnoy, 77 Wash.U.L.Q. (1999), 619, 627.

132 Hazen, The Law of Securities Regulation, $6^{\text {th }}$ ed. 2009, p. 437 et seqq.; Möllers/Rotter/ Schulte, Ad-hoc-Publizität, 2003, \$6 Rdn. 17 et seqq.

133 Bucklo, Scienter and Rule 10b-5, 67 Nw.U.L.Rev. 562 (1972).

134425 U.S. 185, 96 S.Ct. 1375, 47 L.Ed.2d 668 (1976).

135 Ernst \& Ernst v. Hochfelder, 25. U.S. 185, 197, 96 S.Ct. 1375, 1982, 47 L.Ed 2d 668 
Although the Supreme Court's landmark decisions in Hochfelder and Aaron ${ }^{136}$ left the question open whether recklessness was sufficient for a damages claim, the majority among the courts of appeal consider reckless actions sufficient for liability. ${ }^{137}$ Recklessness is defined as a "lesser form of intent [rather] than merely a greater degree of ordinary negligence" 138 . Plaintiff has to prove that the defendant could have predicted the deception of the plaintiff as a reasonable result of his action. Whether or not he intended the deception is irrelevant. ${ }^{139}$

In practice, it is difficult if not impossible for the plaintiff to prove the defendant's intent. The courts may draw the conclusion that the defendant acted recklessly from certain facts ${ }^{140}$, however, this is rarely the case. The requirements for assuming scienter are very high. ${ }^{141}$ For instance, a court did not draw the conclusion of scienter where a profit of $\$ 1.6$ million was achieved by insider trading. ${ }^{142}$

According to the Private Securities Litigation Reform Act of 1995, plaintiff has to prove that the defendant purposely violated Rule $10 \mathrm{~b}-5 .{ }^{143}$ To prove that the defendant knowingly published wrong statements, the plaintiff has to state that the defendant had knowledge of the correct facts. ${ }^{144}$

\section{bb. The Dodd-Frank Act}

From 1980 to 2010, credit rating agencies were excluded from expert liability ${ }^{145}$ in the United States. ${ }^{146}$ This rule was repealed by the Dodd-Frank Wall

(1976); Hazen, The Law of Securities Regulation, 6 $6^{\text {th }}$ ed. 2009, p. 457; Aaron v. SEC, 446 U.S. 680, 695, 100 S.Ct. 1945, 1954, 64 L.Ed.2d 611 (1980).

136 Aaron v. SEC, 446 U.S. 680, 695, 100 S.Ct. 1945, 1954, 64 L.Ed.2d 611 (1980).

137 Anixter v. Home-Stake Production Co., 77 F.3d 1215, 1232 (10th Cir. 1996); In re Advanta Corp. Securities Litigation, 180 F.3d 525, 539 (3rd Cir. 1999).

138 Sanders v. John Nuveen \& Co., 554 F.2d 790, 793 (7th Cir. 1977).

139 AUSA Life Insurance Co. v. Ernst \& Young, 206 F.3d 202 (2nd Cir. 2000).

140 Cox/Hillman/Langevoort, Securities Regulation, 5th ed. 2006, p. 670.

141 Rothman v. Gregor, 220 F.3d 81, 94-95 (2nd Cir. 2000); San Leandro Emergency Medical Group Profit Sharing Plan v. Phillip Morris Cos., 75 F.3d 801, 814 (2nd Cir. 1996).

142 Rothman v. Gregor, 220 F.3d 81, 94-95 (2nd Cir. 2000).

143 In re Theragenics Corp. Securities Litigation, 137 F.Supp.2d 1339 (N.D.Ga. 2001); Section $21 \mathrm{D}(\mathrm{b})(2) \mathrm{SEA}, 15$ U.S.C. $\$ 78 \mathrm{u}-4(\mathrm{~b})(2)$ : “In any private action arising under this chapter in which the plaintiff may recover money damages only on proof that the defendant acted with a particular state of mind, the complaint shall, with respect to each act or omission alleged to violate this chapter, state with particularity facts giving rise to a strong inference that the defendant acted with the required state of mind".

144 In re First Union Corp. Securities Litigation, 128 F.Supp.2d 871 (W.D.N.C. 2001).

145 "expert liability" according to Sec. 7 and 11 Securities Act of 1933 (SA).

146 Liability exclusion, codified by Rule 436(g) SA. 
Street Reform and Consumer Protection Act ("Dodd-Frank Act") in June $2010 .{ }^{147}$ Since then, credit rating agencies are subject to regular expert liability if they agree to their ratings' being included in issue prospectuses and applications for quotation. The new regulation requires the credit rating and the agency's name must be published for every issue of asset-backed securities (ABS). ${ }^{148}$ Thus, ratings are a necessary part of listing procedure and for ABS issue offers. In order to avoid expert liability, NRSROs ${ }^{149}$ refused to consent in their ratings' publication. ${ }^{150}$ Consequently, the market for asset-backed securities collapsed. The SEC reacted by issuing non-action letters ${ }^{151}$, a non-application decree for duties of disclosure existing according to Regulation $\mathrm{AB}$. The SEC abstains from executing the duties of disclosure in the above-mentioned cases, thus making non-rated transactions possible. ${ }^{152}$ This SEC recommendation was originally in force for a limited time-frame only, but has recently been renewed indefinitely. ${ }^{153}$ Liability rules in the U.S. therefore remain obscure despite an enacted law; a clarifying statement by the SEC must be awaited. ${ }^{154}$

Generally, credit ratings are protected as "speech" under the First Amendment, practically ruling out any liability for "faulty" ratings. ${ }^{155}$ This jurisprudence was questioned in 2009. ${ }^{156}$ Another trial before the U.S. District Court for the District of New Mexico ${ }^{157}$ might point in the same direction: The court

147 \939G Dodd-Frank Act, H.R. 4173.

148 SEC, Regulation AB, Item 1120, of November 23, 2010, http://www.sec.gov/divi sions/corpfin/cf-noaction/2010/ford072210-1120.htm.

149 Credit Rating Agencies and Nationally Recognized Statistical Rating Organizations.

150 Harper, 68 Wash. \& Lee L. Rev. 1925, 1926, 1964.

151 For an example see the non-action letter issued to the Ford Motor Company; U.S. Securities and Exchange Commission, Regulation AB, Item 1120, Nov. 23, 2010, http://www.sec.gov/divisions/corpfin/cf-noaction/2010/ford072210-1120.htm.

152 Morgenson, Hey, S.E.C., That Escape Hatch Is Still Open, The New York Times, March 5, 2011, http://www.nytimes.com/2011/03/06/business/O6gret.html.

153 See the non-action letter issued to the Ford Motor Company; U.S. Securities and Exchange Commission, Regulation AB, Item 1120, Nov. 23, 2010, http://www.sec. gov/divisions/corpfin/cf-noaction/2010/ford072210-1120.htm.

154 See Brody/Hanawalt, Dodd-Frank: Rating Agencies And The ABS Market, Law 360, January 24, 2011, http://www.bingham.com/ExternalObjects/Docs/Dodd-Frank\% 20 Rating\%20Agencies\%20And\%20The\%20ABS\%20Market_\%286247\%29.pdf; Letzler, Expert liability for rating agencies, October 3, 2011, The National Law Journal, http://www.law.com/jsp/nlj/PubArticleNLJ.jsp?id=1202517569077\&slreturn=1.

155 Nagy, Credit Rating Agencies and the First Amendment: applying Constitutional Journalistic Protection to Subprime Mortage Litigation, 94 M.L.R. 2009, 140, 142.

156 Abu Dhabi Commercial Bank v. Morgan Stanley E Co. Inc., 651 F. Supp. 2d 155 (S.D.N.Y. 2009).

157 Genesee County Employees Retirement System v. Thornburg Mortgage Securities Trust 2006-3, 825 F. Supp. 2d p. 1082, 2011 WL 5840482 (Thornburg). 
denied the defendant credit rating agencies Moody's, S\&P and Fitch to resort to the freedom of speech because the ratings were shared only with a small group of investors. ${ }^{158}$ In this case, according to the court, ratings do not deserve the broad protection given by the First Amendment making the agencies generally liable. ${ }^{159}$ However, proving a violation of a duty of disclosure or fraudulent behavior was only successful where S\&P was concerned. The case against Moody's and Fitch was dismissed. The court did, however, allow the plaintiff to amend the complaint accordingly. ${ }^{160}$ The case was settled in early 2013 for \$ 11 million. ${ }^{161}$ The court missed the chance to set a trend for the liability of credit rating agencies in the U.S. strengthening the rights of impaired investors.

\section{cc. Lebman under U.S. Law}

A successful claim under U.S. law would encounter problems. Currently, credit rating agencis are excluded from expert liability due to the non-action letters issued by the SEC. Even in case the SEC would reverse the non-action letter, a claim will not likely be successful. The rating still is protected under the First Amendment as "speech". The opposite judgment of the Court for the District New Mexico ${ }^{162}$ will not withstand a judicial examination by a higher court. It contradicts the scope of protection intended by the First Amendment to link the protection to the number of listeners.

Notwithstanding the foregoing concerns, even a successful claim under Rule $10 \mathrm{~b}-5$ would have little prospect of success. The plaintiff has to prove that the defendant acted with intent, which is difficult if not impossible. The case would, however, appear in different light if S\&P, instead of not changing the rating at all, had uprated Lehman in spite of the negative media. Such a behavior can without any doubt be seen as "scienter", as it sends a "positive" signal and affirms investors in their investment decision.

158 Genesee County Employees Retirement System v. Thornburg Mortgage Securities Trust 2006-3, 825 F. Supp. 2d p. 1082, 2011 WL 5840482 (Thornburg), p. 1236.

159 Genesee County Employees Retirement System v. Thornburg Mortgage Securities Trust 2006-3, 825 F. Supp. 2d p. 1082, 2011 WL 5840482 (Thornburg), p. 1236 et seq.

1602011 WL 5840482, 130, 148 (Thornburg).

161 http://securities.stanford.edu/filings-case.html?id=104431; Robbins, Geller Rudman \& Down LLP announcing the proposed settlement: http://www.businesswire.com/ news/home/20130104005733/en/Robbins-Geller-Rudman-Dowd-LLP-AnnouncesProposed\#.UvIPqmtJnW4.

162 Genesee County Employees Retirement System v. Thornburg Mortgage Securities Trust 2006-3, 825 F. Supp. 2d p. 1082, 2011 WL 5840482 (Thornburg). 


\section{c. Common problems}

The bottom line of all three presented rules is that the burden of proof remains the most critical point especially concerning the intent of the credit rating agency. Reversal of the burden of proof is considered the solution. It is difficult for the investor to prove that he relied on the rating, but it is just as difficult for the credit rating agencies to produce evidence. They will have problems proving that an investor did not rely on a rating. The same applies for the proof of the intent of the agency: the investor cannot prove the intent of the agency, as it is an interior position. But for the agency, it is impossible to prove having no intent.

Still the liability regime as it is today is not effectively offering legal protection. The regulation adopted falls short of the original Commission's proposal especially with regard to the burden of proof and the requirement of "reasonable reliance" excluding all institutional investors.

\section{Is Liability the solution?}

It is the hope and aim of the new liability regime to ensure a better quality of ratings and protect investors and issuers. But perhaps a liability is not the solution for the main problem existing when it comes to rating. One of the main aims of the European Union is emphasized in the most recent Regulations: the reliance of the market on ratings in general should be reduced. This aim might even be undermined by the new liability regime.

It is undisputed that credit rating agencies played a role in the financial crisis. It remains mysterious why investors trusted in ratings. While the informational value of ratings declined, dependency grew. The reason for this could be the growing amount of references made to rating in laws and directives. At the same time, investors started to use ratings instead of own risk analysis. The combination of these two factors leads to a climate where the trust in ratings was bigger than the informational value the rating generated. The financial industry forgot that ratings are always a prediction of a future development which cannot, as is the nature of the future itself, be foreseen or predicted. Every attempt to predict the future is usually based on experiences from the past thus making it impossible to predict developments that have not been there before such as the most recent financial crisis.

Every reference to credit ratings in rules and regulations gives (too) much authority to these ratings. Hence it can be argued that abolishing these references is a first step in breaking the power of the credit rating agencies. Introducing a civil liability regime at the same time as abolishing the references in 
regulation is diametrically opposed to this goal. A liability regime suggests that ratings can be trusted with making correct predictions on how a financial instrument will perform in the future. This has been proven wrong not only during the financial crisis.

The final goal in regulating credit rating agencies should be conveying the message that ratings are only one opinion on how a financial instrument might perform in future and does not replace an own risk assessment. Furthermore, every market participant should be aware that predicting the future is impossible for everyone and there is always a risk left. One way to achieve this could be a waiver of any reference to ratings in laws and regulations including a liability regime.

\section{Conclusion}

\section{a. Breaking the Oligopoly}

Still, dependency on the leading agencies' ratings is too high. The Commission's proposal to require two ratings is positive. However, it does not suffice as can be seen in the newest developments of Roland Berger's European credit rating agency. ${ }^{163}$ Even today, potential investors seem doubtful about the agency's future acceptance on the market. The political players want more competition but consider it "a question for market participants, not the government" 164 . For the given reasons, the legislator refrains from direct interference with the rating system but does not see alternatives to creating a government-run European credit rating agency. Legally requiring a (second) European rating could "kill two birds with one stone". Not only would it break the market's oligopolistic structure, the legislature could also give a necessary jump-start to small European or new rating agencies such as Roland Berger. The legislature could help the European agencies to gain access to the credit rating market and at the same time improve competition and, consequently, quality.

\section{b. Liability de lege ferenda}

The introduction of a liability regime as such has to be appreciated and is a great step forward. It may be difficult for investors to claim damages, but credit rating agencies will have to fear consequences as gross transgressions

163 Europäische Ratingagentur von Roland Berger auf der Kippe, FTD, April 16, 2012.

164 Kotthaus, Speaker of the German Minister of Finance, FAZ, April 16, 2012, p. 11. 
will result into a liability under art. 35a. In addition, national liability regime offer impaired investors a further possibility for compensation. However, some factual requirements have to be changed. Infringements of the requirements of Annex III lead only to damages if they have affected the rating. The investor has to prove this effect which will hardly be possible. This could easily be remedied by introducing the assumption that every breach of Annex III duties affects the rating unless the credit rating agency can prove otherwise. The credit rating agencies know that their ratings are relevant for market participants. Thus it seems plausible too relieve the requirements for causation and damage. Both could easily be achieved by a reversal of proof as initially proposed by the Commission. ${ }^{165}$ 